日消外会誌 34 ( 1 ) : 15 20, 2001年

原著

\title{
切除不能・再発胆管癌・胆囊癌・膵癌に対する expandable
}

\section{metallic stent 症例の予後に関する検討}

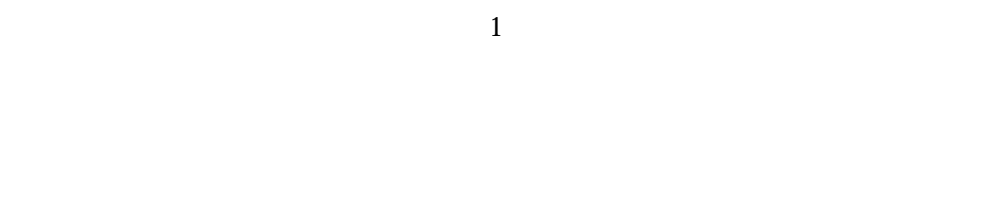

悪性胆道閉塞に対する減黄処置としての expandable metallic stent (EMS) は, 患者のQOL の改善 を目的として使用されてきた．今回，我々は切除不能または再発胆管癌・胆囊癌・膵癌において光の 有用性を予後および退院可能患者数に関して検討した【対象と方法】1988年より1999年 3 月までに当 科を受診し，EMSによる胆道内瘦術を施行した，切除不能または再発胆管癌17例・胆囊癌10例・膵癌 10例の EMS 挿入後の生存期間，退院可能率に関して検討した.【結果】膵癌・胆囊癌・胆管癌における 生存期間の中央值は, 弚れ2.0月，4.7月，7.3月であり，膵癌・胆囊癌・胆管癌の順に有意に予後が 不良であった . 膵癌の退院可能患者率は20\%と有意に低かった.【結語】EMS 挿入後の胆管癌・胆囊癌 に対しては良好な QOL が得られるものの, 膵癌の生存期間は短く退院率が低いことより, 原疾患の進 行度に応じだ治療法が選択されるべきである。

\section{はじめに}

膵・胆道悪性腫瘍は，画像診断の向上や手術手技の 進歩にかかわらず，切除不能症例は少なくなく，また 手術後の再発率が高く，弚の予後は極めて厳しいのが 現状である . 弚れらの悪性胆道閉塞に対する非観血的 内瘻術としての expandable metallic stent（以下， EMS) は，患者の quality of life (以下，QOL) の改善 を目的として使用され，近年増加傾向にある.EMS の有用性は報告されているが'1)，黄疸を呈した切除不 能または再発胆管癌・胆囊癌・膵癌症例に限つた検討 は行われてない.今回，我々は消化器外科的立場より， そ林におてEMSの有用性を長期予後を中心に検 討した。

\section{1. 対象}

\section{対象と方法}

1988年 1月より1999年 3 月までに奈良県立医科大学 第1外科を受診し, 切除不能または術後再発と診断さ れ，EMSによる胆道内瘦術を施行した，胆管癌17例・ 胆囊癌10例・膵癌10例を対象とした . 年齢は33歳から 81歳，中央值は63歳であった．男21人，女16人であっ

$<2000$ 年10月31日受理 $>$ 別刷請求先 : 青松 幸雄 ７634-8522 橿原市四条町840 奈良県立医科大学第 1 外科
た、乥れ光れの内訳は, 胆管癌では, 試験開腹術およ び姑息術症例が 5 例 , 非開腹症例が11例，再発症例が 1例であった．胆囊癌では，关れ光れ2例，5例，3例 であった . 膵癌では, 弚れ光れ 3例，5例，2例であっ た . 試験開腹術および姑息術となった10症例の主な原 因として，腹膜転移によるもの6 例 , 高度の腫瘍局所 進展によるもの2例，大動脈周囲リンパ節転移による ものが1例であった . 非開腹となった21症例の主な原 因として，高度の腫瘍局所進展によるもの 7 例，多発 性肝転移によるもの6 例 , 大動脈周囲リンパ節転移に よるもの 3 例, 腹膜転移によるもの 1 例, 高齢による もの3 例 , 全身状態不良によるもの1例であった . 再 発は 6 症例あり，再開腹および画像診断，腫瘍マーカー により診断した . 腹膜転移によるものが 2 例 , 多発性 肝転移によるものが 2 例，大動脈周囲リンパ節転移に よるものが1例，局所再発によるものが1例であった . 一方, 疾患群別の高度リンパ節転移陽性例数, 肝転移

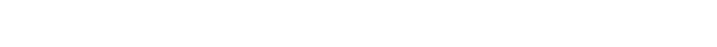
は17例中 9 例， 7 例，6例，胆囊癌では10例中 5 例，2 例，5例，膵癌では10例中 5 例，6例，4例であった (Table 1) .

\section{EMS挿入の方法 \\ 当院放射線科にて，経皮経肝的に細径のイントロ}


Table 1 Patient and tumor status at the EMS implantation

\begin{tabular}{lccc}
\hline & cholangiocarcinoma & gallbladder cancer & pancreatic cancer \\
\hline patient status & 11 & 5 & 5 \\
no laparotomy & 5 & 2 & 3 \\
$\begin{array}{l}\text { exploratory laparotomy } \\
\text { palliative surgery }\end{array}$ & 1 & 3 & 2 \\
$\begin{array}{r}\text { recurrent disease } \\
\text { tumor status }\end{array}$ & 9 & 5 & 5 \\
$\quad$ lymph node involvement & 7 & 2 & 6 \\
$\quad$ liver metastasis & 6 & 5 & 4 \\
\hline peritonitis carcinomatosa & 17 & 10 & 10 \\
\hline$\quad$ total numbers & & & \\
\hline
\end{tabular}

Fig. 1 Several types of expandable metallic stents used in this study

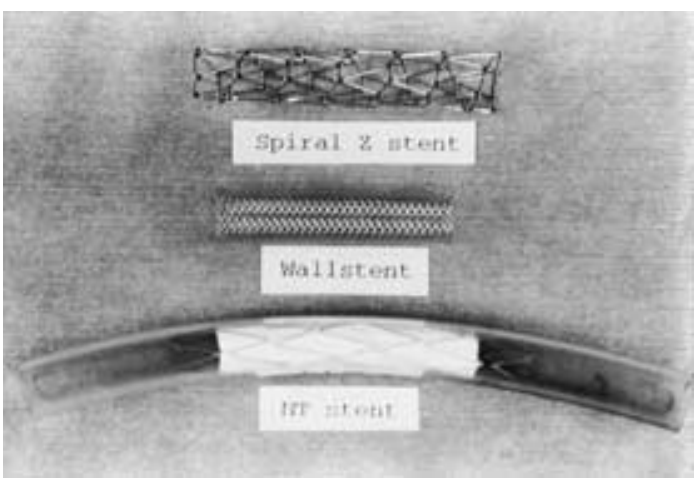

デューサーを用いて，EMS留置が行われた．外瘻 チューブは,3日間解放後閉鎖し ,EMS の開存性 ,血清 ビリルビン值の正常化を確認した後に抜去した .EMS の種類は spiral 型あるいは modified 型のZ stent , ま たはW allstent，NT stent などを単独あるいは組み合 わせて用いた (Fig. 1) . 肝門部胆管閉塞に対しては主 にZ stent を，総胆管閉塞に対してはW allstent や力 バーステントのNT stentなどを用いた .

3. 抗癌斉・放射線治療の方法

放射線療法は,Liniacによる照射を行い,内照射線量 は総量で30Gy から100Gy，外照射線量は総量で20Gy から30Gy であった . 全身化学療法はマイトマイシン , $5 F U$,シスプラチンの組み合わせによる静脈内投与 ,肝 動脈注入用リザーバーよりのアドリアマイシン投与， 腹腔内シスプラチンの投与が行われた .

\section{4. 検討項目}

EMS 留置後の合併症, EMS 留置後の入院期間・減 黄期間・生存期間と，生存期間に及ぼす諸因子，退院
に及ぼす諸因子を検討した . 初回 EMS 挿入後の退院 患者数および, 各群の退院患者数を全症例数で割り算 出した退院率に関して検討した。

5 . 統計学的処理の方法

各群間における分散分析は, Fisher 法にて検定し た . 各群間の生存率は, Kaplan-Meier 法にて算出し, Logrank 法にて検定した . 多变量解析は, 生存期間に 関しては Cox 比例ハザードモデルにて, 退院に関して はロジスティック回帰分析にて行い検定した . 各群間 の比率の分析は Steel 法にて検定した . 兴れ光れの検 定で， $p<0.05 の と き ，$ 統計学的有意差ありとした .

\section{結果}

\section{1. 抗癌斉・放射線治療}

胆管癌，胆囊癌，膵癌に対し，抗癌剂あるいは放射 線治療を施行した症例は光れ光れ，17例中12例，10例 中 5 例，10例中 4例であった(Table 2) . 胆管癌では， 内照射が 2 例，外照射が 1 例，内外照射が 9 例であり， 内照射線量は30Gy から100Gy，外照射線量は20Gy か ら30Gy であり，内照射の1例に対し肝動注が行われ た . 胆囊癌では, 内照射が 0 例，外照射 (30Gy) が 2 例，内外照射 (32Gy/57.5Gy) が 1例であり，外照射の 1例に対し全身化学療法が, 全身化学療法のみが 1例 に，腹腔内抗癌斉投与が 1 例に行われた . 膵癌では， 外照射 (30Gy) が1例，全身化学療法のみが 3 例に行 われた .

2. 合併症

胆管炎・肝膿瘍を胆管癌群の4例に認めたが，経皮 経肝的にドレナージ術を行い軽快した．弚のほか，重 篤な合併症は認められなかった .

3. 入院期間，減黄期間，生存期間

胆管癌群・胆囊癌群・膵癌群における EMS 挿入か

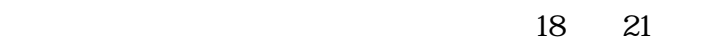


Table 2 Patient numbers and treatments received after the EMS implantation

\begin{tabular}{|c|c|c|c|}
\hline & cholangiocar cinoma & gallbladder cancer & pancreatic cancer \\
\hline $\begin{array}{l}\text { no irradiation therapy /no } \\
\text { chemotherapy }\end{array}$ & 5 & 5 & 6 \\
\hline irradiation therapy only & 11 & 1 & 1 \\
\hline chemotherapy only & 0 & 2 & 3 \\
\hline $\begin{array}{l}\text { irradiation therapy and } \\
\text { chemotherapy }\end{array}$ & 1 & 2 & 0 \\
\hline total & 17 & 10 & 10 \\
\hline
\end{tabular}

Table 3 Admission, jaundice-reduced and survival period in the each group after the EMS implantation

\begin{tabular}{lccc}
\hline & $\begin{array}{c}\text { admission period }(d) \\
(\text { means } \pm \text { SD })\end{array}$ & $\begin{array}{c}\text { jaundice-reduced period }(m) \\
(\text { means } \pm \text { SD })\end{array}$ & $\begin{array}{c}\text { survival period }(\mathrm{m}) \\
(\text { means } \pm \text { SD })\end{array}$ \\
\hline cholangiocarcinoma & $18 \pm 24^{\mathrm{a}}$ & $6.9 \pm 5.5^{\mathrm{d}}$ & $9.6 \pm 7.7^{f}$ \\
gallbladder cancer & $21 \pm 26^{\mathrm{b}}$ & $4.8 \pm 3.9$ & $6.1 \pm 3.9$ \\
pancreatic cancer & $47 \pm 25^{\mathrm{c}}$ & $2.2 \pm 2.5^{\mathrm{e}}$ & $2.6 \pm 2.7^{\mathrm{s}}$ \\
\hline
\end{tabular}

${ }^{c} v^{a}(p=0.007), v^{b}{ }^{b}(p=0.028) \cdot{ }^{e} v^{d}(p=0.013) \cdot g^{g} s^{f}(p=0.005)$.

Fig. 2 Cumulative patient survival curves of cholangiocarcinoma, gallblader caner and pancreatic caner after the EMS implantation

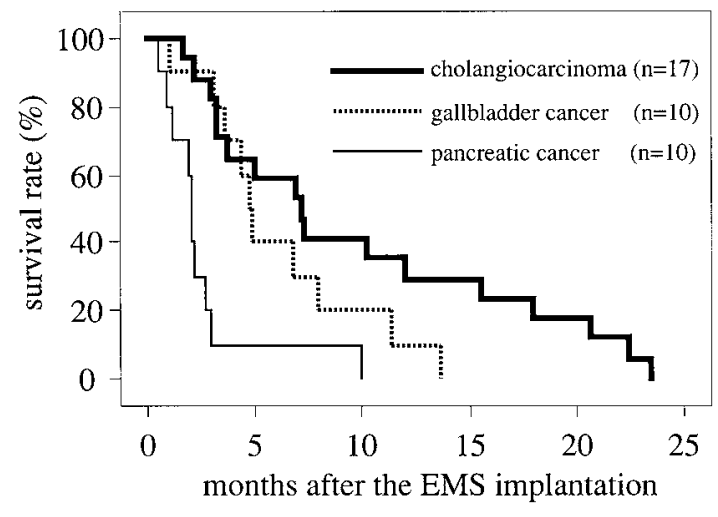

47日であり, 膵癌群は, 胆管癌群, 胆囊癌群に比べ有 意に入院期間は長かった．胆管癌群・胆囊癌群・膵癌 群における平均減黄期間は光れ光れ，6.9か月，4.8か月， 2.2力月であり, 胆管癌群は, 脺癌群に比べ有意に減黄 期間は長かった . 胆管癌群 ・胆囊癌群・脺癌群におけ る平均生存期間は光れ光れ，9.6か月，6.1か月，2.6か月 であり，膵癌群は，胆管癌群に比べ有意に生存期間は 短かった (Table 3). 胆管癌・胆囊癌・脺癌における EMS 挿入後の生存曲線を示した (Fig. 2) . 全例24か月
以内に死亡した . 胆管癌・胆囊癌・脺癌における生存 期間の中央值は，光れ艺れ7.3か月，4.7か月，2.0か月で あり, 膵癌・胆囊癌・胆管癌の順に予後が不良であつ た .膵癌群は, 胆管群, 胆囊癌群に対し, 乥れ光れ $p<$ $0.001, p=0.011$ と有意に予後が不良であつた . 胆管群 は胆囊癌群に対し,$p=0.11$ と有意差は認めなかった .

\section{4 . 生存期間に及ぼす因子の多変量解析}

疾患群，放射線照射，抗癌斉投与，EMS 挿入前の患 者の status, 高度リンパ節転移の有無 , 肝転移の有無 , 癌性腹膜炎の有無の 7 因子を生存期間に及ぼす因子と して多变量解析すると, 疾患群, 放射線照射, 肝転移 の3因子において有意差が認められた(Table 4) .胆管 癌，胆囊癌は脺癌に対し有意に予後良好であった . 放 射線照射群は非照射群に対し有意に予後良好であっ た . 肝転移群は肝転移のない群に対し有意に予後不良 であった .

\section{5 . 退院に及ぼす因子の多変量解析}

疾患群, 高度リンパ節転移の有無, 肝転移の有無, 癌性腹膜炎の有無の 4 因子を退院に及ぼす因子として 多变量解析すると, 疾患群においてのみ有意差か認め られた . 膵癌群は, 胆管癌群, 胆囊癌群に対し, 有意 に退院ができなかった .

\section{6 . 退院可能患者数および退院率}

胆管癌 - 胆囊癌 - 脺癌の退院患者数 (退院率) は, 弚れ光れ，17例中16例（94\%），10例中 8例（80\%）， 
Table 4 Multivariate analysis of prognostic factors for the patient survival after the EMS implantation

\begin{tabular}{llccc}
\hline & & $\mathrm{P}$ & relative risk & $95 \% \mathrm{Cl}$ \\
\hline group & $\begin{array}{l}\text { pancreatic cancer } \\
\text { cholangiocarcinoma }\end{array}$ & 0.001 & 1.00 & \\
gallblader cancer & 0.090 & 0.345 & $0.039-0.398$ \\
irradiation therapy no & & 1.00 & $0.101-1.181$ \\
& yes & 0.012 & 0.319 & $0.130-0.780$ \\
liver metastasis no & & 1.00 & \\
& yes & 0.001 & 13.129 & $3.799-45.373$ \\
\hline
\end{tabular}

Table 5 The numbers and the percentage of patients discharged from the hospital after the EMS implantation

\begin{tabular}{lccc}
\hline & cholangiocarcinoma & gallbladder cancer & pancreatic cancer \\
\hline $\begin{array}{l}\text { patient numbers discharged } \\
\text { from the hospital }\end{array}$ & 16 & 8 & 2 \\
total numbers & 17 & 10 & 10 \\
\hline percentage $(\%)$ & $94^{\#}$ & $80^{\# \#}$ & $20^{*}$ \\
\hline & & $*$ vs\# $(p<0.001),{ }^{*} v^{\# \#(p=0.026)}$
\end{tabular}

10例中 2 例 $(20 \%)$ であった．脺癌患者の退院率は， 胆管癌患者および胆囊癌患者の退院率に対し光れ光れ $p<0.001, p=0.023$ と有意に低かった . 胆管癌患者と 胆囊癌患者の退院率には有意差は認めなかった（Table 5) .

\section{考察}

胆道癌・脺藏癌における治療法は外科的切除法が第 1選択とされている.しかしながら,他の消化器癌と比 ベ, 診断時には高度進行例が多く，切除率が低く，切 除可能であっても非根治的治癒切除となる場合が多 く，予後が不良である．このようなことより，治癒切 除術をめざした門脈塞栓術を併用した拡大肝葉切除 術, 肝葉 ·肝十二指腸間膜 - 脺頭十二指腸切除術, 拡 大膵頭十二指腸切除術などの拡大術式が考案され施行 されてきたが , 期待されたほどの予後の改善は得られ ていない(2)3).さらに，再発癌に対する根治的外科治療 法は皆無に近い，一方，切除不可能な癌や再発癌に対 しても化学療法や放射線療法が試みられているが , 有 効なものは開発されていない.

閉塞性黄疸に対する姑息的減黄術として，胆管空腸 吻合術などの外科的内瘻術が以前より行われてきた . Shepherd ら ${ }^{4} や A$ nderson $ら^{5)}$ の報告によると，姑息術 としての外科的胆道内瘻術と endoprosthesisによる 非観血的胆道内瘻術の間には, 患者の生存率などにお いて両者間に有効性の差は認めなかった .このような ことを踏まえ，minimal invasive therapy の観点より， 悪性腫瘍による閉塞性黄疸に対し , endoprosthesisに よる胆道内瘻術が行われるようになってきた .

悪性疾患による胆道閉塞に対する endoprosthesis による種々の胆道内㾪術方法が考案されている.1985 年にW right ら によって考案された expandable metallic stent を胆道内瘻術に応用することにより，長期 間にわたり大口径で良好な開存性を有する EMS が開 発，使用されるようになった．非手術的なinterventional radiology の手法を用い，日本においても汎用さ れるようになった . 使用する endoprosthesis の材質 は , ポリエチレン製やテフロン製の plastic stent と金 属製の expandable metallic stent に大別される . plastic stent は，挿入法が簡便であり抜去や再挿入が容易 であることや，費用が安価であることなどの長所があ るが, チューブ内胆泥付着による閉塞が問題となり， 平均開存期間は3か月から 6 か月とされている 一方， expandable metallic stent は , メッシュ状構造による ステント内面の胆管上皮の被覆によるバイオフィルム 形成を抑え，大口径のステント内腔がえられ，平均開 存期間は12か月から14か月と延長した7).この報告と 比べ, われわれの検討した症例の平均開存期間は，切 除不能・再発癌を対象としたことにより，胆管癌で6.9 か月, 胆囊癌で4.8か月, 脺癌で2.2か月と短かった . EMS 挿入の問題点としては，費用が高価であることや 
ステント内腔への腫瘍の ingrowth や overgrowth な どによる再閉塞がある . 後者への対策としてステント 内へのステントの再留置や複数個のステント留置, 材 質の改良などが挙げられ，更なる開存期間の延長や， 合併症の軽減が図られている。

一方で, 材質面での改良に伴い,EMS挿入患者の長 期予後をめざした . 局所療法の併用が試みられるよう になってきた。体外照射内腔照射による放射線療法， 全身化学療法や肝動注化学療法, マイクロ波凝固療法 などの局所併用療法の有用性が報告されている . 吉岡 ら》は肝門部および肝内閉塞症例に対し開存率のみな らず生存率向上にも寄与したこと, 池田 ${ }^{11}$ (放射線療法 とマイクロ波凝固療法との併用療法により生存期間の 延長に寄与したことから，積極的な併用療法を推奨し ている．しかしながら, 本研究において多変量解析を したところ，併用療法別では放射線療法は統計的な有 意差は認めたが , 抗癌斉投与は予後に及ぼす因子とは なりえなかった .この理由として, 対象症例の違いや， 単変量と多変量による解析方法の違いが反映されたの かもしれない .

本研究における対象患者は, 閉塞性黄疸を呈する切 除不能あるいは再発した胆道癌・膵癌とした .この理 由として, 消化器外科疾患を扱っているものが必要と しているのは, このような根治術は不可能であるが， 姑息的治療は必要である患者のEMS 留置後の長期予 後などの検討である EMS 治療の有用性は，吉岡ら”に より多数報告されているものの, 対象症例は, Stage Iや Stage II などの手術可能症例も含まれているもの と考えられる . 切除不能あるいは再発患者を対象とし た報告はないことより，外科的立場に立った interventional radiology としての EMSの有用性の検討を行っ た。

EMS 挿入後の生存期間の中央値は, 胆管癌が 7 か 月, 胆囊癌が 5 か月, 膵癌が 2 か月と, 胆管癌, 胆囊 癌, 膵癌の順に, 統計学的に有意に予後は良好であつ た .このことは光れ癌が有する, 局所進展の速 さや転移能などの悪性度を反映しているものと考えら れた.EMS 挿入後の長期予後に関して,吉岡ら 管癌が 6 か月, 胆囊癌が 4 か, 膵癌が 4 か月と, 池 田 $^{11}$ は胆管癌が 6 か月, 胆囊癌が 4 か月, 膵癌が 3 か月 と報告しており われわれの結果とほぼ同樣であった . 生存期間に影響を与える因子の多変量解析におい て, 疾患群，肝転移，放射線照射に有意差を認めた . 一方，抗癌剂による化学療法, EMS 挿入前の患者の status , 高度リンパ節転移 , 癌性腹膜炎などの因子は , 多変量解析において予後に及ぼす因子とはなりえな かった.

EMS 留置の主たる目的は，内瘻化することにより， 患者から外瘻チューブ管理の煩雑さより解放すること にある .このことより患者のQOL の改善に寄与する というものである.この指標として，挿入後の外瘻 チューブの抜去率, 開存期間や再閉塞率などの検討が 行われてきだ). しかしながら これらのみでは十分で はなく，簡便かつ全体的な QOL 評価法として，EMS 挿入後の退院が可能であったかどうかを検討した . 興 味深いことに，各疾患群間で検討すると，膵癌群では $80 \%$ の症例でEMS 挿入後も退院が可能とはならず， 胆管群や胆囊群と比べ退院率が有意に低かった . 退院 に及ぼす因子の多変量解析においても, 疾患群におい てのみ有意差が認められた .この理由として, 膵癌患 者では減黄のみでは光の他の症状や病状の改善が期待 できないことが考えられ，結果的に退院不能となって しまう.これらのことより,EMS 挿入後の生存期間も 加味すると, 胆管癌 ・胆囊癌においてはEMS挿入後 の予後は比較的良好で退院も可能となる症例が多く， 良い適応と考えられた .一方, 膵癌においては, 肝転 移の有無など，個々の症例を慎重に検討した上でEMS 以外の処置を含めた適切な減黄方法を選択することが 肝要と考えられた .

切除不能または再発胆管癌に対しては良好な QOL がえられ，切除不能または再発胆囊癌に対しては比較 的良好な QOL がえられるものの，切除不能または再 発膵癌のEMS 挿入後の生存期間は短期であることよ り，原疾患の進行度に応じた治療法が選択されるべき である

\section{文献}

1) 池田靖洋 : 切除以外の治療一特にステンティング など一. 日消外会誌 32: 75-79, 1999

2) Kosuge $T, Y$ amamoto J, Shimada $K$ et al : Improved surgical results for cholangiocarcinoma with procedures including major hepatic resection. A nn Surg 230 : 663-671, 1999

3) 吉川達也, 大田岳洋, 新井田達雄ほか: 胆囊癌に対 する肝膵同時切除 (HPD) の適応と治療成績. 日 外会誌 99: 717-721, 1998

4) Shepherd H, Royle G, Ross A et al : Endoscopic biliary endoprosthesis in the palliation of malignant obstruction of the distal common bile duct : a randomized trial. Br J Surg 75 : 1166-1168, 1988 
5) A nderson JR, Sorenson SM, Kruse A et al : Randomized trial of endoscopic endoprosthesis versus operative by pass in malignant obstructive jaundice. Gut $30: 1132-1135,1989$

6) Wright $\mathrm{KC}$, Wallace $S$, Charnsangavej $C$ et al : Percutaneous endovascular stents : A n experimental evaluation. Radiologe $156: 69-72,1985$
7) 吉岡哲也, 打田日出夫, 阪口 浩ほか : Expandable metallic biliary endoprosthesis—悪性胆道閉 塞190症例の検討 . 胆と膵 $18: 877$-882, 1997

8) 鐘撞一郎,吉岡哲也，打田日出夫ほか：悪性胆道閉 塞に対する W allstent を用いた胆道内瘦術 . 胆と 膵 $16: 1167-1174,1995$

\section{Expandable Metallic Stent to Patients with the L ocally A dvanced or Recur rent Cholangiocar cinoma, Gallbladder Cancer and Pancr eatic Cancer \\ Y ukio A omatsu, Y oshiy uki Nakaj ima, Hiromichi Kanehiro, Michiy oshi Hisanaga, Saiho Ko, Mitsuo Nagao, T sunehiro Kobay ashi, Hiroshi A nai*, Hideo U chida*and Hiroshige Nakano \\ First Department of Surgery, Department of Radiology*, Nara Medical U niversity}

A $n$ expandable metallic stent (EMS) for the palliation of malignant biliary obstruction has been used for improving the quality of life. In this study, we examined its long-term efficacy in cases with the locally advanced or recurrent carcinomas of the bile duct, gallbladder and pancreas. From January 1988 to March 1999 , EMSs were placed in 37 patients who had been diagnosed as having locally advanced or recurrent cholangiocarcinoma $(n=17)$, gallbladder carcinoma $(n=10)$ and pancreatic carcinoma $(n=10)$. T he median survival of the patients with cholangiocarcinoma ( 7 months) and gallbladder carcinoma ( 4 months) was significantly longer than that of those with pancreatic carcinoma ( 2 months) after EMS implantation. T he discharged percentage of patients of the pancreatic carcinoma $(20 \%)$ was significantly low er than that of those with cholangiocarcinoma (94\%) and gallbladder cancer (80\%) discharged from the hospital. In conclusion, EMS is a relatively low-invasive therapy that offers a better quality of life to patients with locally advanced or recurrent cholangiocar cinoma and gallbladder cancer. We should consider whether the EMS or a plastic stent is the better choice in patients with the locally advanced or recurrent pancreatic carcinoma.

Key words : expandable metallic stent, malignant biliary obstruction, quality of life

〔Jpn J Gastroenterol Surg 34 : 15-20, 2001〕

Reprint requests : Y ukio A omatsu First Department of Surgery, Nara Medical Univer sity 840 Shij ocho, Kashihara, 634-8522 JA PA N 